\title{
Problems and Countermeasures in the Construction of China-Russia Free Trade Area
}

\author{
Nan YAN \\ Harbin University of Commerce, Harbin, China \\ 83566986@qq.com
}

Key Words: China-Russia free trade zone, Construction, Countermeasures.

\begin{abstract}
The free trade area is an important form of regional economic integration. On the basis of expounding the necessity of the China-Russia free trade zone, this article analyzes the problems existing in the establishment of China-Russia free trade zone from the angles of commodity size and structure, trade liberalization, trade cooperation system, trade service system, and cultural differences. And made a targeted response.
\end{abstract}

\section{Analysis of the Necessity of Establishing China-Russia Free Trade Area}

\section{It is Beneficial to Increase the Trade Volume between the Two Sides by Strengthening the} Economic Ties between China and Russia

With the successful establishment of the China-Russia free trade zone, the two governments gradually abolished government intervention. In the import and export trade, not only will tariffs be eliminated, but also non-tariff barriers will be reduced to a large extent, and efforts will be made to fully realize free trade. China and the two countries must inevitably close their economic exchanges and strengthen economic cooperation, thus increasing the trade volume between the two sides. Based on the comparative advantage theory and the characteristics of the industrial structure of the two countries, China can export clothing, electronics and other products to Russia, and Russia can export to China resource-relevant products such as fuels and raw materials. China and Russia can give full play to the factors of production, labor, and The complement between energy and other aspects will not only promote the balanced development of the regional economy of the two countries, but also fully coincide with the economic development strategies of the two countries. The establishment of the Sino-Russian free trade zone will enable Russia's products to enjoy preferential treatment measures such as tariff reductions and exemptions that other non-parties do not have in the trade zone. These countries will naturally invest in the trade zone, not only through production technology and management experience. The introduction of adjustments to Russia's product mix has improved the types of Chinese exports, and has also promoted the effective operation of human capital markets and the construction of infrastructure.

\section{It is Conducive to Enhancing the Political Influence of Both Sides by Enhancing Political Mutual Trust between China and Russia}

The development of the world economy has promoted more than a decade of strategic cooperation partners between China and Russia and will surely play an irreplaceable role in the international economic and political affairs. This will enable the two countries to maintain friendship and constantly deepen their understanding. Based on a timely basis to change the status of the economic role, that is: from the initial economic cooperation evolved into today's free trade. However, deep-rooted cultural and traditional differences and unpredictable political rifts have caused divergence, contradictions, and conflicts between China and Russia. The establishment of Sino-Russian free trade zones is based on common economic interests and the "China threat theory." Will be a good solution. The establishment of a free trade zone in China is a requirement and embodiment of mutual benefit between China and Russia. It is also a portrayal of the symbiosis and interdependence between the two countries. These are all based on a mechanism of mutual trust. The existence of a mutual trust mechanism has created peace and security. The living environment 
of the two countries has led to a more stable relationship, the gradual elimination of differences and more active consultations. These have undoubtedly strengthened the contacts, communication and exchanges between the two parties. The seemingly irreconcilable contradictions and conflicts will gradually ease, and the economic development Mutual support is strengthened, demand in import and export tends to be stable, economic efficiency is improved, and social welfare is improved. The influence of positive ability is continuously expanding, and the influence of negative ability is continuously reduced. If the Sino-Russian free trade area is not successfully constructed, trade creation benefit will not be given. The two countries have played an active role.

\section{It is Conducive to Stabilizing the National Security of China and Russia so as to Protect the Interests of Both Parties}

Today's economic globalization is also an era full of challenges and threats. China and Russia, as world powers, must have the same understanding of security needs and interests appeals, and will surely play a heavy role in maintaining world peace and promoting regional economic development. Big country should have the responsibility and responsibility. Conflicts and conflicts such as the North Korea nuclear issue have caused many threats in China and Russia, especially in Northeast Asia. These threats not only affect the environmental stability of economic development, but also affect the adjustment of the strategic structure in Northeast Asia, and the effective solution of these issues is Only when China and Russia conduct active dialogues and make full use of geopolitical and resource advantages to develop close cooperation can we ensure the sharing of economic interests and ensure political and national security. The construction of China-Russia free trade zone is undoubtedly an ideal solution.

\section{It is Conducive to Expanding Bilateral Trade by Deepening Cultural Exchanges between China and Russia}

The existence of culture is not only the source of conflicts and conflicts, but also an effective lubricant for the exchanges and cooperation between countries, through deep-seated cultural exchanges between Chinese and Russian personnel exchanges, business activities, and tourism activities. It will help ease cultural conflicts and understand and identify cultural differences. It will surely expand the cultural varieties and trade space of China and Russia. The former include Chinese antique calligraphy and painting and Russian handicrafts. The latter include traditional dining, entertainment and high-end financial insurance.

\section{Problems in the Construction of China-Russia Free Trade Area}

\section{The Scale of Sino-Russian Trade is Relatively Small, and the Structure of Trade Commodities has been Simplified}

As everyone knows, from the perspective of population size and land area, both China and Russia can be regarded as the world's heavyweights, but in terms of trade volume between the two sides, they are not in line with the status of heavyweights mentioned above. According to statistics, in 2017, the bilateral trade volume between China and Russia was 840 US dollars. Compared with other large countries, the scale is still relatively small. In 2017, the bilateral trade volume between China and the United States reached 580 billion U.S. dollars, although we also see that China and Russia The trade volume between the two countries increased year by year (in 2017, the Sino-Russian trade volume increased by $20.8 \%$ compared with 2016), but the gap between the scale and other countries is still relatively large. The small scale of Sino-Russian trade is not only reflected in the transaction volume, but also related to the simplification of the trade commodity structure between the two countries. China's imports from Russia are mainly resource-based products such as pulp, logs, and chemical products. China's exports to Russia are mainly labor-intensive products such as beverages, vegetable oils, and foods, while product additions Products with higher values and higher technological content account for a smaller proportion. Once the Sino-Russian free trade area is completed, the bilateral trade commodity structure will 
surely exhibit diversified characteristics and trends. From the dialogue between the heads of state of China and Russia in the New Year in 2018, we can see that in the coming years, China and Russia will continue to optimize the bilateral trade structure, strengthen cooperation in the fields of energy, equipment manufacturing, agriculture, and aerospace, and regard the digital economy, such as big data, the Internet of Things, and smart cities as new growth points for cooperation.

\section{Different Levels of Trade Liberalization between China and Russia}

Trade liberalization is based on the theory of comparative advantage in international trade theory. It is the basic objective of trade that the World Trade Organization and the GATT have consistently advocated. It mainly means that trade between countries should be market-oriented. When importing a country's goods and services, it is necessary to gradually reduce unnecessary restrictions, and it is possible to provide the marketization process of preferential trade treatment. Through the comparison of tariff levels between China and Russia, we can see the degree and level of trade liberalization between China and Russia. In 2016, China continued to fulfill its tax reduction commitment when joining the World Trade Organization, and insisted that the 2016 MFN tax rate remained unchanged. The total tariff level remained at 9.8\%, while Russia's current tariff level was approximately $10.5 \%$, which is bound to Trade in goods and services with certain comparative advantages has formed an artificial barrier.

\section{The System of Trade Cooperation between China and Russia is not Perfect}

Sound institutional arrangements and effective institutional mechanisms are prerequisites and guarantees for the smooth and orderly implementation of economic activities. In order to achieve healthy, stable, and effective development, trade activities between countries must rely on the institutional cooperation mechanism. For a long time, one of the biggest obstacles to the trade activities between China and Russia has been the lack of sound institutional arrangements. The mixed trade order has seriously affected the cooperation between the trading companies of the two countries, resulting in low credibility of both parties, low performance of contracts, and short-term economic growth. Sex and other adverse consequences. One of the reasons for this consequence is that the two countries' trade modes and levels are at a low level because of the lack of institutional basis for cooperation; the second reason is that a sound market economy requires a sound legal mechanism and management mechanism. The two countries have not been able to fully provide the above two mechanisms. Therefore, the bilateral trade between the two countries is prone to gray customs clearance, bad competition, and shoddy and so on, and irregular market behavior.

\section{Incomplete System of Trade Services between China and Russia}

Smooth international trade activities not only need sound laws and regulations and multi-level trade commodity structure, but also need a perfect trade service system. The missing trade service system in China and Russia mainly manifests itself in the following aspects: First, the current trade volume of goods passing through the Russian border is relatively small and often stranded. The key constraint is that the customs clearance procedure in Russia is very tedious and corruption is serious. , The efficiency of the handling personnel is not high, the implementation of international standards is not in place, discriminating against the valuation link of Chinese export products leads to the increase of the cost of trade goods; second, Russia does not keep pace with the times and the improvement still follows the traditional commodity inspection and quarantine that is higher than the current implementation standards of similar commodities in China. The system, which virtually obstructed the normal trade exchanges between China and Russia, and thirdly, Sino-Russian trade adopts the settlement of domestic currencies between China and Russia because of the unregulated financial order and unsound financial management mechanism of Russia and the two countries The fact that the two countries set up only a single settlement account can not play an important role in the course of Sino-Russian trade, and naturally impede the normal exchange of trade. Fourth, China and Russia have poor communication of information and there is no relatively authoritative intermediary service organization. China and Russia are unable to acquire each other in a timely and effective manner Valuable information on aspects of customs market development, investment 
environment and government policy.

\section{Difference between the Cultural Concepts of China and Russia}

Culture has inherent differences, it is a concept, an attitude, acts on the human heart, like the lubricant applied to the gears, so that all economic activities effectively operate. Cultural concepts also profoundly affect the values, thinking patterns, and behaviors of all citizens. It is a factor that cannot be ignored in international trade. Chinese culture is deeply influenced by the traditional oriental Chinese culture and Russian culture is deeply influenced by Western ideas. Therefore, both China and Russia in terms of religion, school of thought, political system, way of thinking, value orientation, etc. There are big differences.

\section{Countermeasures and Suggestions for Promoting the Construction of China-Russia Free Trade Area}

\section{Perfecting China-Russia Service Trade System Strengthen Multi-field Cooperation}

The role of services in international trade and the national economy should not be underestimated. The contribution of services to the gross national product is increasing. More and more countries have found that a large proportion of their GDP is created by the service industry. Not only traditional service industries such as medical care and insurance, but also new services such as finance have made even greater contributions. As a result, countries in the world have reached a consensus on the importance of service trade, and they must understand services just like goods trade. trading. As trade in services is not yet very developed, China and Russia should actively construct a multi-level and diversified supporting trade development service system such as legal policies, financial investments, tax insurance, and logistics and distribution. In order to reduce transportation time and improve transportation efficiency, it is necessary to vigorously develop China-Russia logistics industry, in order to improve Sino-Russian trade efficiency and reduce import and export risks, vigorously develop financial insurance and consulting industry, in order to alleviate the shortage of human resources and promote labor service cooperation, vigorously develop labor services. The service industry, in order to regulate bank settlement and promote information circulation, should vigorously develop the financial insurance service industry.

\section{Improve the Quality of Export Commodities}

Market economy is a kind of legal economy at the same time, it is also a kind of credit economy. Credit and reputation are the basic characteristics of market economy. Credit must be emphasized in international trade. Commodity quality and quantity are a reflection of credit in international trade. Quality is the sum of the quality and characteristics of commodities. Therefore, we should increase the quality supervision of China's export commodities, prevent counterfeiting, shoddy goods, and make false goods so that good things can meet the needs of domestic people while also representing the Chinese national image. And to the level of manufacturing to the world, increase the research and development of high-tech content and high value-added goods, thus establishing a brand of goods to enhance the competitiveness of the international market, at the same time also require relevant personnel engaged in Sino-Russian trade to establish a brand concept and brand awareness. In order to avoid the recurrence of "gray customs clearance", China must do a good job in monitoring the production of goods and undermine the international image. The government must do a good job of macro-control of foreign trade companies, improve the structure of goods to adjust export methods, and establish brands and enterprises. The long-term strategic goal of credit.

\section{High-Level Officials of China and Russia Should Reach a Consensus on the Establishment of China-Russia Free Trade Zone}

The healthy development of Sino-Russian trade depends on many factors. A well-regulated and sound Sino-Russian trade order is one of the key elements. Sino-Russian trade should follow the rules of the World Trade Organization, namely, the principles of free trade, national treatment, and most favored nation treatment. Principles and fair competition principles. These principles have 
been adhered to in the Sino-Russian trade and, to a certain extent, it also means that both sides are in a good position to build a free trade zone as soon as possible, but more importantly, China and Russia must reach a consensus for this purpose. The top officials of the two sides, including relevant experts and officials, must hold meetings for the construction of the trade zone; relevant experts should draft the topics for negotiations, long-term planning, and periodic key schedules; and write research reports that both parties agree with and accept. In addition, China and Russia should gradually eliminate each other's ideological and cognitive biases, and convince from the perspective of strategic interests and overall interests that to achieve sustainable development of trading economy, maximization of benefits, and long-term strategic benefits, we must actively sign free trade. The agreement and free trade agreement have important strategic significance. It is an effective catalyst for cooperation between China and Russia in the areas of investment, energy, environmental protection, technology, and finance.

\section{China and Russia Should Establish a Good Political Trust}

As mentioned above, China and Russia must speed up the process of establishing a Sino-Russian border economic and trade cooperation zone, and they must actively formulate a plan to achieve a win-win free trade zone. The development of these tasks requires both sides to have good political mutual trust as a prerequisite and guarantee. The long-standing strategic partnership between China and Russia has played an inestimable role in maintaining regional and international affairs. Actively establishing and improving effective consultation and cooperation mechanisms can deepen communication and exchanges between the two countries and effectively safeguard the relations between China and Russia. Fundamental interests.

\section{Acknowledgements}

The study was supported by "Training program for young creative talents of general higher schools in Heilongjiang Province in 2017 (UNPYSCT-2017212)" and "Research team support project of Harbin University of Commerce in 2016(2016TD015)”.

\section{References}

[1] Xiang Yijun. Analysis of the Trade Effect of Establishing China-Russia Free Trade Area [J], Siberian Studies, 2015(12)

[2] Xiang Yijun. An analysis of the establishment of basic trade effects in China-Russia bilateral free trade area[J], Business Studies, 2016(1)

[3]Rong Hongxia. Research on the support path of financial policy in the construction of China-Russia border free trade area [J], study and exploration, 2016 (4) 